\title{
The Valuation and Market Rationality of Internet Stock Prices
}

\author{
Eli Ofek \& Matthew Richardson*
}

* Stern School of Business, New York University. We would like to thank participants at MIT, NYU and the NBER summer institute for helpful comments and suggestions. 


\begin{abstract}
This paper provides an analysis of some existing as well as new evidence of the relation between market prices and fundamentals in the internet sector over the period January 1998 to February 2000. Appealing to results across a broad class of outcomes, we demonstrate a strong, circumstantial case against market rationality In particular, we investigate (i) the level of internet stock prices given their underlying fundamentals, (ii) responses of stock prices to information-based events, and (iii) the volatility of internet prices. We review several potential explanations of these phenomena, including one based on heterogenous beliefs across investors who are subject to short sales constraints. We provide a discussion of the empirical evidence supporting this latter explanation.
\end{abstract}




\section{Introduction}

By February 2000, the internet-related sector equaled $6 \%$ of the market capitalization of all U.S. public companies. This was a sector, however, which in aggregate had negative earnings. To many practitioners and academics alike, this represented "irrational" valuation levels most commonly seen in virgin markets, or in extreme cases like the South Sea bubble of 1720 or Tulipmania in 1637 Holland, ${ }^{1}$ not in the most well developed capital market in the world.

Market rationality is of paramount importance to financial economists for a number of reasons and, therefore, not surprisingly, one of the most studied topics (e.g., see Fama $(1970,1998)$ and Shleifer (2000)). From an investor's point of view, participation in financial markets and allocation of assets across one's portfolio depends crucially on one's belief about the efficiency of markets. Alternatively, from a corporate finance perspective, the allocation of capital and investment (or lack thereof) in positive net present value projects is fundamentally determined by one's view of the market's rationality.

This paper provides a comprehensive look at the rationality of one particular sector of the economy, notably that of internet-related businesses. We focus our analysis in three particular areas which demonstrate quite extraordinary behavior of the internet sector. The first area involves traditional valuation metrics for firms and what they imply for internet firms during this period. Integrated into this analysis is the growing literature in accounting on how internet-based metrics fit into a firm's valuation. The second area takes specific corporate finance events, such as spinoffs, etc..., and illustrates welldocumented cases of the breakdown of the law of one price, rational response to information, and the like. The third area focuses on a topic which has received somewhat less attention, namely the volatility patterns of internet stocks versus "old economy"

\footnotetext{
${ }^{1}$ Of course, not all economists even agree that these episodes represent irrational bubbles, e.g., Garber (1989).
} 
firms. We find it is difficult to reconcile the "excessive" volatility of the internet sector given the usual measures of private information within a microstructure setting.

When asset prices exhibit anomalous behavior, financial economists often point to illiquidity as the root cause. That is, the financial anomaly does not have great importance as few transactions can take place at the prevailing price. However, this was not the case for internet stocks. Individuals could, and did, trade large amounts at the prevailing measured prices. For example, consistently through the 1998-2000 period, pure-play internet firms represented as much as $20 \%$ of the dollar volume in the public equity market even though their market capitalization never exceeded $6 \%$. That these prices are real is bad news for financial economists, like ourselves, who believe in the rational formation of asset prices.

The fact that we are able to document bizarre behavior of internet prices will not come as a surprise to academics or practitioners alike. Nevertheless, we feel it is a useful exercise to report both the characteristics and magnitude of the so-called internet bubble, thus, not relying on anecdotal evidence alone. Arguably, the most interesting question is not whether there was a bubble, but how did it come about, why did it persist, and what caused it to burst? These questions pose quite a challenge to financial economists. Given our view that well developed capital markets are primarily driven by rational investors, why didn't these investors come into the market and drive prices back down to fundamental levels?

There is a growing literature that addresses this question, and our paper summarizes this view (see Ofek and Richardson (2001) for a detailed analysis as it applies to the internet sector). Shleifer (2000) provides us with a reasonable way to look at the issue of how human behavior can impact financial asset prices. He argues that there are two necessary conditions: (i) irrationality on the part of some investors, and (ii) limits to arbitrage such that this irrationality cannot get drowned out. There is substantive evidence that the internet sector satisfies these two conditions.

With respect to the first condition, few economists will argue with the supposition that there exists irrational investors, just with whether they matter or not. In fact, a number of studies show that individual investors (i.e., retail) make irrational trading decisions (e.g., Barber and Odean $(1999,2002))$. Furthermore, there is a large literature 
in behavioral finance describing the various idiosyncracies of investors (e.g., see Hirshleifer (2001) for a survey of these findings). While some of these findings can be taken with a gain of salt, there are several supportive facts: (i) the internet sector had many more retail investors than institutional ones compared to other stocks (Hand (2000), Ofek and Richardson (2001)), (ii) these investors were inexperienced to the extent this was their first foray into investing (Barber and Odean (2001)), and (iii) the internet sector itself was new and faced considerable uncertainty about its valuation prospects. This latter fact is an important part of the story as presumably even irrational investors cannot ignore certain, or indisputable, facts.

With respect to the second condition, even though there might have been plenty of capital available for "rational" trading, we argue that the market had limited ability to short internet stocks either because they were unwilling or found it too difficult to do so. We discuss the existing evidence which is based on several characteristics of the data: (i) the downside risk of shorting internet stocks, (ii) the amount of short interest in internet versus non-internet stocks, (iii) the rebate rate on short interest for internet versus noninternet stocks, and (iv) put-call parity violations in the options market for internet versus non-internet stocks.

In a world with limited arbitrage and significant numbers of irrational investors, there is considerable support in the finance literature for prices deviating from fundamental value. The basic idea roots back to the original CAPM theories, in particular, Lintner's (1969) model of asset prices with investors having heterogenous beliefs. In his framework, asset prices are a weighted average of beliefs about asset payoffs with the weights being determined by the investor's risk aversion and beliefs about asset price covariances. While the asset prices are equilibrium-determined to the extent that they reflect the underlying beliefs about payoffs, one could argue that for the internet the beliefs of enough of these agents were overly optimistic, or, perhaps more harshly, crazy. As Lintner (1969), and many others after him, show that in this world short sales restrictions can lead to widely inflated prices. (See, for example, Miller (1977), Jarrow (1980), Chen, Hong and Stein (2000), and Duffie, Garleanu and Pedersen (2002)). However, when short sales restrictions no longer bind investors, then prices fall back down. We argue that the unlocking of literally hundreds of billions of dollars of shares in 
the internet sector in Spring 2000 had the equivalent effect of removing short sales restrictions. This in turn led to internet prices reflecting the aggregate view across investors, not just the optimistic ones - leading to the so-called internet bubble burst.

\section{Internet Prices: A Snapshot}

This paper studies various characteristics of internet-related companies over the period January, 1998 to February, 2000. We use the sample of firms constructed by Ofek and Richardson (2001) which uses Morgan Stanley's breakdown of various internet sectors - (i) portals, (ii) infrastructure companies, (iii) infrastructure services, (iv) software, (v) commerce, (vi) consulting and applications, (vii) financial services, (viii) multi-sector, (ix) vertical portals, (x) marketing and advertising services, and (xi) B2B commerce. Essentially, the sample restricts itself to pure internet firms which yields a total of 400 companies in the above internet-related sectors. Table 1 gives a further breakdown of these 400 companies by internet sector and "old economy" counterpart industry.

Figure 1 graphs an equally-weighted portfolio of our internet sample, the Nasdaq and the S\&P 500. The incredible rise in internet values from 1998 to 2000 has to be considered one of the most amazing asset pricing phenomenons of our time. These numbers are part of the cornerstone of our analyzing the excessive price levels and volatility of internet-related stocks.

Figure 2 reports both the aggregate daily volume and market capitalization of the internet sector throughout the 1998 to 2000 time period. The figure suggests an active, liquid market for the internet stocks during the sample. In fact, relative to the universe of firms, the average volume per stock is three times higher for internet firms. That is, while internet firms represent $6 \%$ of the public equity market during February 2000, the pure internet sector represents $19 \%$ of the daily volume. This stylized fact about volume suggests that the internet was not just a few investors trading small amounts of stock with each other, but a wide scale market in which large amounts of stock exchanged hands at these prices. 
The next three sections of the paper evaluate the rationality of internet price levels in three different ways. First, we explore the level of internet stock prices relative to their fundamentals using standard valuation metrics. Second, we investigate some examples of extreme events and look at the response of internet stock prices to information (or lack thereof). Third, using various measures, we document the volatility of internet stocks. We show that their volatilities are large relative to non-internet stocks, yet not consistent with commonly used measures of private information being the root cause.

\section{Were Internet-Related Stock Prices Too High?}

The extraordinary rise in internet values as shown in Figure 1 has generally been called the "internet bubble". The fact that prices fell in March of that year, and continued to fall throughout 2000, gave some credibility to this designation. However, one cannot infer necessarily from this ex post realization that market values did not in fact reflect fundamental values about cash flows. Tautologically, changing expectations about cash flows or discount rates, coupled with realization of various internet fundamentals, could also explain the rise and drop in prices. We, as well as anyone else, will not be able to definitively answer this question here. Instead, we follow a long line of previous academic research (e.g., French and Poterba (1991) and Shiller (2000), among others) to provide the reader with an understanding of what the market had to expect to justify such high valuations.

French and Poterba (1991) use Miller and Modigliani's (1961) model for stock valuation to investigate the level of Japanese equity prices in the 1980s. The model is a convenient way to look at equity prices because it provides the reader with a way to gauge the growth rate required to justify the level and movement in P/E ratios over time. In particular, Miller and Modigliani show, that for a firm with supernormal return opportunities $r^{*}$ over T periods,

$$
P / E=\frac{1}{r}\left\{1+\frac{k\left(r^{*}-r\right)}{r-k r^{*}}\left[1-\left(\frac{1+k r^{*}}{1+r}\right)^{T}\right]\right\}
$$


where $k$ is the fraction of earnings invested in the supernormal projects and $r$ is the discount rate. Now consider the internet sector and further assume that for the first $\mathrm{T}$ periods these firms earn supernormal return $r^{*}$ with a fraction $k=1$ invested; after this initial period, these firms act like their "old economy" counterparts and achieve similar $\mathrm{P} / \mathrm{E}$ ratios. In this case, it is possible to show that equation (1) can be rewritten as

$P / E=\left(\frac{1+r^{*}}{1+r}\right)^{T} P /^{O L D}$

A nice property of equation (2) is that, as long as we are willing to make an assumption about these firm's long-run $\mathrm{P} / \mathrm{E}$ ratios, we can estimate how large the supernormal returns have to be on current investments relative to required returns in order to justify current $\mathrm{P} / \mathrm{E}$ levels. In other words, we do not need to know the magnitude of discount rates. Equation (2) will form the basis for our analysis to follow.

We calculate the aggregate earnings of each of the internet sectors using Compustat. Even though these companies are public, many of them are startups and have negative earnings, so that even the aggregate earnings number is negative. This is due to significant costs in building the business, both from a technological point of view and from extensive marketing and sales costs. As a result, we consider a different measure of earnings potential by backing out the implicit earnings of the sector assuming that the companies in the sector have already achieved income margins of their industry counterparts. $^{2}$ For example, in the ecommerce sector, we ignore the fact that the companies are unprofitable. Instead, given their revenue and the income margins seen in the retailing sector, we assume that the ecommerce sector has already reached the same level of profitability.

Several observations are in order. First, the above assumption about profitability is clearly a "best-case" scenario for the internet sectors. In fact, many of their business models assume that, after some period of time, the scale of their operations will be so large that the added marketing and technological costs of being an internet company are

\footnotetext{
${ }^{2}$ One could take the view that this is equivalent to not treating some of the business costs as expenses, but instead capitalizing them. We thank Stew Myers for this obervation.
} 
swamped and "old economy" margins will be realized. ${ }^{3}$ Second, by accelerating the profitability of the sectors, and essentially assuming that they have reached this stage with probability one, the $\mathrm{P} / \mathrm{Es}$ will be understated, resulting in a corresponding underestimate of what the necessary supernormal returns must be. Third, we estimate the $\mathrm{P} / \mathrm{E}$ ratio by taking the particular internet sector's aggregate market value of equity divided by its implicit earnings. ${ }^{4}$ These earnings are calculated by multiplying its aggregate revenues by the assumed income margin. The assumed income margin is the weighted average margin of its closest "old economy" counterpart.

Table 2 reports this information for the eleven sectors described in Table 1. For example, industry code 5, the ecommerce sector, includes 50 companies with an aggregate market capitalization as of February 2000 of 72.675 billion dollars and with aggregate revenues of 4.459 billion and net income of minus 3.565 billion. Using the industry margins of $1.9 \%$, we can back out implied earnings of 85 million, which gives the industry an implied, new economy $\mathrm{P} / \mathrm{E}$ ratio of 856 . Given an assumption about the old economy $\mathrm{P} / \mathrm{E}$ ratio and the number of years excess returns can be achieved, Equation 5 can then be used to generate how large these returns must be to justify the 856 level.

The results in Table 2 correspond to the eleven internet sectors in aggregate; it is also of interest to document the implied P/Es firm by firm. Figure 3 graphs the distribution of these P/Es across the entire sample of internet-related firms. As seen from the figure, the vast majority of the $\mathrm{P} / \mathrm{Es}$ seem high relative to the types of $\mathrm{P} /$ Es usually represented by firms (e.g., Shiller (2000)). For example, almost $20 \%$ of the firms have P/E ratios in excess of 1500 , while over $50 \%$ exceed 500 . This seems especially large given that the implied $\mathrm{P} / \mathrm{Es}$ are derived from the revenue streams of these firms rather than their earnings.

In order to better understand the implications of these $\mathrm{P} / \mathrm{E}$ numbers, Table $3 \mathrm{~A}$ documents the relative size of supernormal returns, $\left(1+r^{*}\right) /(1+r)-1$, needed to justify the aggregate $\mathrm{P} / \mathrm{E}$ ratio of the entire internet sector under various assumptions about long-run

\footnotetext{
${ }^{3}$ There are clearly some types of internet business models in which the goal is to surpass their old economy counterpart's margins. We ignore these except to point out that earnings move one-to-one with margin increases. The interested reader can, therefore, adjust the $\mathrm{P} / \mathrm{E}$ ratios according to his/her beliefs.

${ }^{4}$ The market value of equity here most likely underestimates the value of the firm. This is due to the fact that internet companies have considerable amounts of stock options which do not get capitalized until the options are exercised.
} 
$\mathrm{P} / \mathrm{E}$ ratios and the time period over which firms can achieve supernormal returns. For an historically high $\mathrm{P} / \mathrm{E}$ ratio of 20 , the internet sector would need to generate $40.6 \%$ excess returns for a 10-year period to justify its current implied $\mathrm{P} / \mathrm{E}$ ratio of 605 . Under the strong assumption that all earnings get reinvested, and even if these opportunities lasted 30 years, excess returns for the entire internet sector still need to be $12.0 \%$. Given Figure 3 , and using the fact that $25 \%$ of the firms have P/Es of 1000 , this implies that $25 \%$ of the firms need $47.9 \%$ excess returns on capital over a 10 -year period.

An alternative way of writing equation (2), and in the more familiar framework of earnings growth rates, it naturally follows that:

$$
P / E \times\left(\frac{1+r}{1+g}\right)^{T}=P / E^{O L D}
$$

where $g$ is the growth rate in earnings (assuming all earnings get reinvested). The intuition of equation (3) is that the drop in $\mathrm{P} / \mathrm{Es}$ from today to the target $\mathrm{P} / \mathrm{E}$ must reflect the fact that earnings grow at a much higher rate than expected returns (i.e., the cost of capital).

Assuming a cost of capital of $0 \%$, i.e., zero expected returns over the next few decades, the results previously described in Table $3 \mathrm{~A}$ correspond to the required growth in earnings. Thus, even if investors required no return on the internet sector, earnings growth would have to range between $12.0 \%$ (for 30 years) to $40.6 \%$ (for 10 years) at a target $\mathrm{P} / \mathrm{E}$ of 20 . How large is $40.6 \%$ for 10 years? Chan, Karceski and Lakonishok (2001) report the distribution of earnings growth over a 10-year period from 1951-1998 for both all firms and the two largest deciles. ${ }^{5}$ At the most extreme distribution tail they report (i.e., at 98\%), the growth rates are $31.3 \%$ and $22.6 \%$, respectively. Thus, our results are extraordinary for several reasons: (i) the required growth rates are between 50$100 \%$ higher than the highest $2 \%$ of existing firms, (ii) the growth rates reflect an entire sector, not just the ex post performance of the very best firms, and (iii) these growth rates imply a cost of capital of $0 \%$.

At a more reasonable cost of capital, Table 3B provides the various growth rates in equation (3) needed to justify P/Es between 10 and 30 over different time periods. For

\footnotetext{
${ }^{5}$ As Chan, Karceski and Lakonishok (2001) point out, their sample is subject to survivorship bias. In particular, their numbers are biased upwards as their sample reflects the more successful firms.
} 
example, at a weighted average cost of capital of $16 \%$, these excess returns translate to $63.1 \%$ growth rate in their implied earnings. This is as much as three times higher than the top $2 \%$ earnings performers from the Chan, Karceski and Lakonsihok sample. Even with a long-run $\mathrm{P} / \mathrm{E}$ ratio of 30 , and thirty years of supernormal returns, the growth rate required is still as high as $28.2 \%$.

This analysis is not the first to point out the excessive $\mathrm{P} / \mathrm{E}$ ratios in the stock market during this period (e.g., Demers and Lev (2000) and Shiller (2000)). Beyond the financial press at large, Shiller (2000), for example, shows that the P/E ratios for the aggregate market were at their highest value of any period in the $20^{\text {th }}$ century, including the infamous market crash of 1929 and the "nifty-fifty" of the late 60's. Moreover, we have focused on the internet sector and shown that these $\mathrm{P} / \mathrm{E}$ ratios were much higher than the aggregate markets". In fact, putting the "best-case" scenario assumptions aside, the results of Table 3 imply that, for a significant period of time, the market would have to expect excess returns on their investments of $30-40 \%$ above their cost of capital. That is, in a competitive product market with few barriers to entry, and across over 400 public firms representing $6 \%$ of the public market capitalization, expected continual, aggregate profits of this magnitude would appear extraordinary. At the minimum, this represents strong circumstantial evidence of investors being optimistic about the future growth opportunities of this sector.

Aside from optimism, what else can explain these excess returns on capital?

One unique characteristic about internet-related firms during this period is that they tended to go public relatively soon after incorporation. One possibility is that the large implied excess returns on capital for internet firms reflects the firm's age rather than an overvaluation argument. That is, if "old economy" firms had gone public prematurely, and we had gathered data on these companies, we would find similar P/Es. This explanation requires the condition that $\mathrm{P} / \mathrm{E}$ ratios should decline very rapidly as a firm develops. Since most economist's intuition on what is a reasonable excess return on capital derives from experience with old economy companies, it seems worthwhile exploring the possibility that firm age plays an important role. We estimated the crosssectional correlations of various measures of the sample of internet firms, including the implied $\mathrm{P} / \mathrm{E}$ of each firm and its age. Though the relation is negative, i.e., younger firms 
have higher P/Es, it is barely so, yielding a correlation of 0.09 . Thus, less than $1 \%$ of the cross-sectional variation in P/Es can be explained by the firm's age. Moreover, this correlation estimate is also not significant from a statistical point of view.

The other related possibility is that today's revenues (and implied earnings measures) are not representative of the future potential of these firms. That is, the valuation relation in equation (2) is not a good approximation in practice. In fact, recent work by Schwartz and Moon (2000) argues that internet companies have so many strategic/real options available to them that standard discounted cash flow-based models are no longer appropriate. However, it is important to point out that these options eventually must translate into revenue streams that reflect the growth rates documented above.

\section{Event Driven Irrationality}

There is a long history in financial economics of analyzing the effect an economic event has on the value of financial assets. The importance of this type of an analysis for studying market rationality has been well-known since Ball and Brown's (1968) earnings announcement study and Fama, Fisher, Jensen, and Roll's (1969) stock-split analysis. The basic idea is that in a rational market prices should immediately reflect the information contained in the event. Conversely, if the event contains very little information, then prices should not move much at all. There have been a series of papers written on financing events in the internet-related sector which document seemingly irrational price responses. These price moves do not only violate conditions like the law of one price, but are also so large in magnitude that explanations are difficult to come by. The one consistent theme, however, is an overly optimistic aggregate belief about the "new economy" firm's potential in the face of other overriding information. The fact that there are a significant number of events that defy rational valuations does not in itself prove gross market inefficiency in the internet sector. It is, however, consistent with the relative high level of internet prices documented in Section III being driven by irrational investors.

Below, we highlight some of our favorite examples: 


\section{A. What Is in a Name?}

When one considers corporate events that should have little effect on the financials of the company, a name change should be high on the list. It may seem plausible to consider a name change as a signal of a firm's intent. However, if that signal is relatively costless, then it probably is not that credible. A more plausible signal probably entails some costly action which signifies a switch in business plans, or, in our case, a transformation towards being an internet company. Alternatively, these firms may already be involved in the internet, yet this information has not gotten disseminated in the marketplace. Changing one's name might represent one additional way to release this information though this does not really explain why rational, smart investors had not already bid the stock price up to reflect public information about the firm's internet activities. In any event, one might expect there to be little stock price reaction, and, in fact, prior to the internet craze, the existing literature provided supporting evidence of this (e.g., Bosch and Hirschey (1989) and Karpoff and Rankine (1994)).

Similar to these earlier studies, Cooper, Dimitrov, and Rau (2000) investigate the stock price response of firms that change their name to an Internet-related name such as dotcom, dotnet or inclusion of the word Internet. Specifically, they look at a sample of 147 firms over the period June 1998 to August 1999 period. These firms tend to be low capitalized firms (e.g., \$54.4 million on average) and almost all trade on the Nasdaq OTC. In contrast to the existing literature, Cooper, Dimitrov, and Rau (2000) document striking results for the stock price responses of these companies. Relative to an Internetmatched portfolio, these firms earn on average 53\% excess returns over the five-day period surrounding the name change announcement with corresponding t-statistics of 13 . Moreover, when the sample is segmented into subsamples based on the firms' involvement with the internet, the announcement day effects still pervade across these subsamples. Thus, the evidence seems more to do with the actual name change than with the internet-related activity level of the firm.

As an example, consider our favorite illustration, that of Zapata corporation. Zapata was founded in 1953 by former President George Bush as an oil and gas company. However, by early 1998, Zapata had transformed itself into a company, albeit 
still "old economy", specializing in meat-casings and fish oil. On April 27, 1998, Zapata's management announced that it was going to form a new company to acquire and consolidate internet and ecommerce businesses. Their first foray into this sector occurred in May when they bid for Excite, which was the second largest internet search directory at the time. Their bid was rejected by Excite's management for its "complete lack of synergy" as quoted in Bloomberg at the time covering Excite's press release. In July, Zapata made further announcements that were starting an internet portal and were in the process of purchasing about 30 internet websites. As the market for internet stocks deteriorated through summer and fall of 1998, Zapata announced that they were reevaluating their internet business strategy and no longer purchasing the websites. On December 23, 1998 the company reversed course again, and stated that they were getting back into the Internet business and will be forming the subsidiary, Zap.com. On this news, shares rose $98 \%$ in New York stock exchange composite trading. This type of example is not atypical and is representative of the Cooper, Dimitrov and Rau (2000) study.

\section{B. Internet Subsidiary Mispricing}

There is a large literature in finance that looks at the value implications of parents and their publicly traded subsidiaries (e.g., see Slovin, Sushka, and Ferraro (1995) and Vijh (1999), among others). Obviously, from the law of one price, assets with the same payoffs must have the same price. Therefore, the subsidiary's public value should be reflected one-for-one in the parent's holding of that subsidiary. Assuming that market imperfections such as taxes and liquidity are not the explanation of breakdowns in the law of one price, violations of this rule are clear evidence of market irrationality. Whether this irrationality violates the no arbitrage restriction depends on investors' ability to conduct arbitrage in the presence of transactions costs, short sales and the derivatives market.

Several recent papers have explored the implications for parent and subsidiary values using a sample of firms that have gone through an equity carve-out transaction (e.g., Cornell and Liu (2000), Lamont and Thaler (2000), Schill and Zhou (2000) and Mitchell, 
Pulvino and Stafford (2001)). That is, these authors consider parent companies who have sold a portion of one of their subsidiaries through a public offering. While the sample of firms are not solely restricted to internet subsidiaries, the majority of firms are in the broader sector most commonly associated with the "new economy". These papers document a number of cases in which the parent's subsidiary holding marked-to-market value exceed the entire parent's value!

As pointed out by some of these authors, these results are similar in spirit to those associated with the closed-end funds discount (e.g., Lee, Shleifer, and Thaler (1991)). The notable exception here is that the parent and subsidiary firms are generally liquid stocks. In fact, explanations based on those from the closed-end funds literature are evaluated and discarded by these authors. With respect to the stronger no arbitrage condition, both Lamont and Thaler (2000) and Mitchell, Pulvino and Stafford (2001) show that, although the mispricings are large, it would be difficult to conduct arbitrage in practice. Though their conclusions regarding the impediments to arbitrage are different, neither paper can and tries to explain why rational investors would buy the subsidiary over the parent in the first place?

As an example of this irrationality, we consider one example considered by both Cornell and Liu (2000), Lamont and Thaler (2000) and Mitchell, Pulvino and Stafford (2001), namely the 3Com's equity carve-out of Palm and its subsequent spinoff. ${ }^{6}$ On September 13, 1999 3Com announced its intentions to take one of its subsidiaries, Palm Computing (a leading manufacturer of handheld devices), public the following year. In fact, on March 2, 2000 Palm became publicly traded on the Nasdaq National Market with 3Com selling a $6 \%$ stake at $\$ 38$ a share which was well above the initial $\$ 14$ to $\$ 16$ range. At the time of the IPO, $3 \mathrm{Com}$ announced its intention to divest its remaining $94 \%$ ownership to 3Com shareholders within six months.

The first day of trading was fairly astonishing as Palm opened at $\$ 145$, reaching a high of $\$ 165$ before ending the day at $\$ 95.06$. This stock price translated to a $\$ 53.4$ billion value for Palm in contrast to 3Com's $\$ 28.5$ billion value. Based on 3Com's 94\% ownership, 3Com's stake in Palm was worth approximately $\$ 50$ billion, giving

\footnotetext{
${ }^{6}$ Lamont and Thaler (2000) provide a very detailed analysis of this event, especially with respect to investors' ability to conduct arbitrage.
} 
substantial negative value to 3 Com's other assets, an almost perfect violation of the law of one price. ${ }^{7}$ Several questions immediately arise with respect to this apparent violation of arbitrage. First, was this violation short-lived, representing "confusion" on the day of the IPO? Second, was their active trading at these misaligned prices? Third, could the arbitrage be performed, and, if so, was it truly riskless? We address these questions below.

Figure 4 graphs the value of Palm and two measures for the value of $3 \mathrm{Com}$ from the IPO date through the spinoff on July 27, 2000. The first measure takes 3Com's stake in Palm and assumes zero value for its existing assets, while the second measure includes the Palm stake as well as existing assets. ${ }^{8}$ As can be seen from the figure, the arbitrage persisted for over two months assuming no value for 3Com's existing assets, and four months giving some value of these assets. Moreover, the arbitrage was large in that the prices deviated by $30-40 \%$ for over one month. The large deviation in prices throughout this period are also economically significant as substantial trading took place at these prices. Figure 4 also graphs the cumulative dollar volume of Palm during the relevant period. While dollar volume reached $\$ 10$ billion during the first two weeks alone, there was still consistent trading throughout the period, ending in approximately $\$ 25$ billion being traded. The effect of buying Palm rather than $3 \mathrm{Com}$, i.e., the arbitrage difference multiplied by the daily volume, is $\$ 3.4$ billion or $\$ 6.1$ billion depending on which value is placed on 3Com. That is, investors "threw away" between $\$ 3$ and $\$ 6$ billion dollars, independent of whether arbitrage was possible.

With respect to the question of arbitrage, the ability to short Palm shares is very much in question. Lamont and Thaler (2000) provide a very detailed analysis of this issue and conclude that, while shorting was possible and in fact performed, it was only on a limited

\footnotetext{
${ }^{7}$ One could argue that (i) the management of $3 \mathrm{Com}$, or its future investment projects, had an incredible negative NPV, and simultaneously (ii) there was a high probability that the complete spinoff was not going to occur. Two facts are inconsistent with these explanations. First, when Palm was spunoff 6 months later, 3 Com's assets were valued at $\$ 13$ a share, which means that its management or assets would have to have improved by a large amount in a shor time. Second, while clearly the probability of a divestiture was not $100 \%$, the probability at the time was considered to be high. Either of these facts are enough to counter the rational explanation.

${ }^{8}$ In particular, at the time, $3 \mathrm{Com}$ had cash and existing operations which in theory had positive value.

Rather than valuing these assets ourselves, we take as a noisy signal the actual market value of the assets at the time of the spinoff, i.e., using the August value of $3 \mathrm{Com}$. Of course, this includes the market
} 
basis. Using evidence on short interest and from the options market, they provide convincing evidence that pure arbitrage was difficult to implement en masse. Mitchell, Pulvino and Stafford (2001) provide complementary evidence and show that the rebate rate on shorts was as low as $-30 \%$. Moreover, under this background, even if an investor were able to borrow the stocks, the risk of getting squeezed was a serious concern. However, even with arbitrage being performed, there are several reasons why it was not riskless. First, the implied volatility of Palm's stock during this period was over $100 \%$ (e.g., on May 9 the implied $\sigma$ for June 30 put was 113 as reported by Bloomberg). Thus, the dynamic hedge necessary to ensure riskless arbitrage would have required frequent rebalancing of the stock position. ${ }^{9}$ Second, as stated in Palm's IPO prospectus, the distribution of the remaining $94 \%$ of Palm shares to $3 \mathrm{Com}$ shareholders was contingent on a ruling from the IRS that the distribution would be tax-free. Although a favorable ruling was likely, it is interesting to note that, from Figure 4, the arbitrage assuming no value for $3 \mathrm{Com}$ 's other assets disappears on May $9^{\text {th }}$, the day the IRS's approval of the tax treatment was announced.

\section{Parent Firm Returns Around the Offer Date of Their Subsidiary IPO}

One related situation to subsection B. above is what happens to the stock price of the parent company on and around the offer date of the IPO of their internet subsidiary. For example, with respect to the case of $3 \mathrm{Com}$ and Palm, the behavior of $3 \mathrm{Com}$ 's return is very typical. Leading up to the IPO date, $3 \mathrm{Com}$ 's stock price increased dramatically as investors began to realize that Palm's IPO was going to be very successful. In fact, it reached an all-time high just before Palm's opening trade on its IPO day. For the rest of the day, however, 3Com's stock price, fell from $\$ 112$ to $\$ 81.80$. There are two possible theories that can explain this pattern in returns. ${ }^{10}$ First, the parent's stock price rise prior

expectation of the assets throughout the March to August period and any unexpected information that could not possibly be known during this period. Thus, this measure is noisy at best.

${ }^{9}$ Of course, to the extent investors care about their portfolio of assets, risky arbitrage can be riskless in a portfolio context if the $\mathrm{Palm} / 3 \mathrm{Com}$ position is uncorrelated with the other assets.

${ }^{10} \mathrm{John}$ Cochrane provides an alternative explanation which is based on liquidity. His argument is that there have always been different prices for similar assets - dollars and T-bills, off-the-run and on-the-run Treasury bonds, different classes of shares. Thus, if one takes the view that the turnover and liquidity is much higher for the subsidiary, then investors might be willing to pay for this, which is why 3Com drops at 
to the offer date may just reflect positive news about the subsidiary's value, while the subsequent fall on the IPO date is indicative of a disappointing final market value of the subsidiary. Of course, this explanation relies on the results being specific to a particular sample though the run-up could be viewed as sample selection of successful IPOs. An alternative view is that investors can only purchase the subsidiary by investing in the parent company. Once the subsidiary is spunoff, investors sell their stake in the parent and replace it with a position in the subsidiary. Though irrational, this sell-off produces the negative effect on the IPO day.

Tezel and Schnusenberg (2000) look at a sample of ten split-off IPOs which is similar to the spin-off case above except that the existing shareholders receive all the newly issued shares of the subsidiary. In anticipation of the IPO, the market price of the parent company rises on average $37 \%$ between the filing and offer date, which contrasts of a $-2 \%$ return on the day of the IPO. Using these facts, Tezel and Schnusenberg (2000) develop an arbitrage strategy based on offsetting positions in the parent and subsidiary depending on the net value of the parent (i.e., after its stake in the subsidiary has been removed). The average daily return across the stocks in the sample is $0.54 \%$ with all the stocks producing positive profitable trading opportunities.

Our favorite example of this phenomenon is the IPO of Marketwatch.com. In particular, on January 15, 1999, the stock price of Data Broadcasting Corp., a 38\% owner (along with CBS) in Marketwatch.com, fell from \$31.18 to \$21.75 even though the IPO return on that day for Marketwatch.com was over 500\%, which at the time was one of the largest one-day returns ever. Of course, there had been a runup in the value of Data Broadcasting from $\$ 17.87$ to $\$ 31.18$ in the prior two weeks. Other information aside, the drop on the IPO day means that the market must have expected a first-day rise of $888 \%$. This belief would have been fairly extraordinary as it would have exceeded the largest one-day return ever, i.e., $697 \%$, which would occur one year later!

\section{Excess Volatility}

the IPO. Though we do not address this reason in the paper per se, it is important to point out that 3 Com itself was a fairly liquid stock by all measures. 
Sections III and IV provided stylized facts on two related, yet separate, points about internet stocks. First, the stock price levels of internet firms tended to be high relative to levels implied by fundamentals. Most important, this divergence was of a magnitude not observed in recent history. Second, the response of stock prices of internet firms to some high profile corporate finance events was anomalous. Again, the interesting characteristic of this stock price behavior is the mere magnitude of the effect. We think equally puzzling, and informative, about internet stock prices is their level of volatility during this period. Thus, in this section, we document some basic stylized facts about internet firms' volatility characteristics.

Excess volatility is generally defined as the volatility in prices that does not correspond to that implied by the underlying fundamentals. It is considered synonymous with the notion of market irrationality and has a long history in the finance literature, e.g., Shiller (1981) and Black (1986) being two notable papers. In Black (1986), noise trading and excess volatility result from the fact that investors either like to trade for no apparent reason or that they trade on what they believe to be "new" information when it is not. In fact, Black goes one step further and takes the controversial view that without noise traders there would be little trading at all. A substantial empirical literature emerged to test some of the implications of this and related work.

The conclusion from this empirical work is generally that volatility is primarily driven by trading rather than public information releases (see, for example, French and Roll (1986), Roll (1988), Barclay, Litzenberger and Warner (1990), and Barclay and Warner (1993), among others). ${ }^{11}$ However, in contrast to Black, there is a substantial fraction of the literature that takes the view that the volatility results more from rational private information traders as in Kyle (1985) than from irrational noise trading per se (e.g., Barclay and Warner (1993) and Ito, Lyons and Melvin (1998) compared to French and Roll (1986)).

While it is difficult to say anything definitively about whether there was excess volatility in the internet sector, it seems worthwhile investigating given its potential link to irrational noise trading. Table 4 reports various volatility measures for both the internet

\footnotetext{
${ }^{11}$ There is not unanimity on this result. For example, Jones, Kaul and Lipson (1994) argue and show evidence in favor of public information, though this work is more the exception than the rule.
} 
sample and the non-internet universe of stocks over the January 1998 to February 2000 period. For example, the average daily volatility across the internet stocks is $7.4 \%$ which translates to an annual volatility of $117.5 \%$ (assuming 252 trading days)! Moreover, this volatility estimate is not driven by a few outliers as the median volatility has a comparable magnitude, i.e., 7.3\%. This contrasts to the non-internet sample which has a mean and median of $3.5 \%$ and $3.0 \%$, respectively. Thus, if one were to use the median estimate, internet stocks have six times the variation of other stocks.

In terms of gathering evidence about volatility-induced trading, it is common for the literature to look at the volatility during trading and nontrading hours, e.g., during the day versus overnight, during temporary market closures, over holidays, over weekends, etc...Table 4 reports the intraday volatility of the internet and non-internet sample over the period using the high-low volatility estimator (e.g., see Parkinson (1980), Garman and Klass (1980) and Beckers (1983)). This estimator uses the difference between the high and low value of the stock price during the day as opposed to the close to close change in the price. Under the assumption that stock prices follow geometric brownian motions, it is theoretically a much more efficient estimator as it uses information about the sample path. ${ }^{12}$ Moreover, it covers the period only in which trading takes place, and avoids some of the problems associated with choosing a set time such as the open, close or midday. Unfortunately, the high-low estimator can be biased downward in small samples if the true sample path of stock prices is not continuous.

The median daily high-low value for internet stocks is $9.9 \%$ versus $3.25 \%$ for the non-internet sample. That is, over a two-year period, stock prices ranged close to $10 \%$ per day over an entire sector of the economy. This result alone seems fairly remarkable and suggests market timing during the day could impact financing decisions! These high-low values translate to mean and median volatility estimators on a daily basis of $6.7 \%$ and $6.9 \%$ versus $2.9 \%$ and $2.4 \%$ for internet versus non-internet stocks, respectively. As well as being economically important, these results are strongly statistically significant.

There are two important observations here. First, the excess volatility of the internet versus non-internet sample carries through to the intraday period in a similar way to the 
24-hour period. For example, the difference between the median intraday and 24-hour volatilities are 40 and 61 basis points for the internet and non-internet sample, respectively. Thus, differences in volatility cannot be associated with volatility outside of either noise or rational private information trading. Second, the intraday volatility is by far the dominant portion of the 24-hour volatility which is consistent with previous studies. This is true even though trading takes place over only one-third the number of hours. ${ }^{13}$ Furthermore, on a percentage basis, this results is stronger for internet stocks. While it can be argued that more public information gets released during trading hours, it is also the case that important events, such as macroeconomic announcements, firmspecific earnings announcements and conference calls, often occur after-hours.

Given the magnitude of the differences between the volatility of the internet and noninternet samples, let us consider the interpretation that this evidence shows substantial more trading-induced volatility occurs with internet stocks. As mentioned above, however, there is substantive previous work that argues trading-induced volatility is rational due to private information. In fact, for internet firms, one might convincingly argue that there is more likely to be more private information because the sector is an emerging industry, has complex and proprietary technology, and has significant ownership by insiders. Alternatively, because of its notoriety and the availability of information, perhaps the exact opposite is true. ${ }^{14}$

We can look to the microstructure literature to get a guide for whether this volatility is being driven by private information. In particular, Glosten and Milgrom (1985) and Madhavan and Smidt (1991), among many others, show how volatility can be broken down into different components, such as public information, private information, and order processing (i.e., direct costs and inventory control management). Though many of these components are not observable, there have been a number of empirical

\footnotetext{
${ }^{12}$ Of course, even though the geometric brownian motion model has a long history in finance, many researchers might consider it a poor assumption, especially in light of the heteroskedasticity and kurtosis that shows up in the data at short intervals.

${ }^{13}$ Over this period, there was a market for after-hours trading, but, on a relative basis, this market is illiquid as measured by the amount of volume.

${ }^{14}$ Schultz and Zaman (2000) and Meulbroek (2000) investigate insider transactions at internet companies and find that, in contrast to usual insider selling at "old" economy firms, excess returns are not negative. Thus, there is little evidence of the usual theory that they are trying to sell overpriced stock. One can view this evidence as generally supportive of the theory that private information, insiders being the extreme example, for internet firms is either not unusually large or does not get incorporated into prices.
} 
investigations which develop methods to infer them (e.g., Glosten and Harris (1988), George, Kaul and Nimalendran (1991), Huang and Stoll (1997) and Madhavan, Richardson and Roomans (1997)). In particular, if one were to assume that the order processing component is similar across stocks (or, in this case, the internet versus noninternet universe), then differences in the bid-ask spread will reflect differences in the magnitude of the private information (i.e., adverse selection) component. Essentially, the spread reflects the fact that dealers need to be compensated for being willing to trade with informed traders. A higher spread coincides with greater costs associated with informed trading or, in other words, a higher private information component. Of course, this higher component also induces higher volatility in returns.

Table 4 reports bid/ask spread measures in both absolute and percentage terms for the internet and non-internet samples as of February 2000. For both measures, the means are substantially lower for the internet sample, e.g., $\$ 0.35$ versus $\$ 0.61$ in absolute terms and $0.7 \%$ versus $1.3 \%$ in percentage terms. That is, the internet spreads are almost $50 \%$ of the non-internet firms. The results diminish somewhat if we look at the medians; nevertheless, they are still lower for the internet sample, e.g., $\$ 0.19$ versus $\$ 0.19$ and $0.5 \%$ versus $0.8 \%$, respectively. Within the context of the above (albeit simple) models, the implication of these lower spreads would be lower volatility ceteris paribus. So why are internet stocks so volatile? Perhaps, the sixfold variation can all be explained by much more fundamental, yet public, information arriving to the market. Alternatively, the results are consistent with irrational, noise trading along the lines of Black (1986). As an anecdotal comment, a February 25, 2000 SEC report on day trading cites industry estimates that as much as $15 \%$ of Nasdaq's daily trading is driven by day trading even though the number of day traders is a small fraction of the market. While this number seems hard to believe, it does suggest a strong link between noise and volume, and, given our results, volatility. ${ }^{15}$

VI. The Internet Bubble

\footnotetext{
${ }^{15}$ Of course, this comment is appropriate if one believes day traders are perfect examples of noise traders.
} 
In this paper, we have provided a number of examples which are consistent with anomalous behavior of the internet sector in terms of its valuation. In particular, the magnitudes of some of the stylized facts are large relative to the universe of non-internet stocks, as well as to previously documented results. If the degree of irrationality is so great, and there certainly exists rational investors (with substantial amounts of capital), why were the severe mispricings not arbitraged away?

Two conditions are necessary for prices to deviate from fundamental value. First, there must be some degree of irrationality in the market. That is, investors' demand for stocks must be driven by something other than fundamentals, whether it be sentiment, overconfidence, or other buzzwords used be behavioral economists. Second, even if a market has such investors, the general argument is that rational investors will drive prices back to fundamental value. For this not to happen, there needs to be some limits on arbitrage.

\section{A. Limits to Arbitrage}

With respect to the equity market, clearly the most important impediment to arbitrage are short sales restrictions. There are essentially two reasons why investors do not short either they do not want to, or it is too difficult to do so. We take both of these cases one by one.

As pointed out by Chen, Hong and Stein (2000), among others, mutual funds are reluctant to short stocks. While this may be more a reflection of previous outdated legislation, such as the Investment Company Act of 1940, than anything real, it is relevant if mutual funds still abide by it. They cite work that shows only a small fraction $(2 \%)$ of mutual funds short stocks, and provide evidence of greater mispricings when mutual funds are absent from the market. Their argument is that, due to an unwillingness to short, institutions tend to avoid "overvalued" stocks. Thus, lower breadth is consistent with a stock being overvalued. Interestingly, as shown by Ofek and Richardson (2001), pension funds were very much absent from the internet sector, which is consistent with this explanation.

With respect to hedge funds, Shleifer and Vishny (1997) argue that, in practice, arbitrage is neither capital-free nor riskless. In a model in which arbitrageurs require 
capital from outside investors and is performance-based, they show that arbitrage may not be successful at forcing asset prices back to their fundamentals. They then hypothesize that fundamental valuation is most flawed in the presence of highly volatile settings. Clearly, as the volatility results in Table 4 show, the prices of internet stocks and their corresponding mispricing occurred in an extraordinarily volatile period. Thus, on some level, the internet sector satisfies the Shleifer and Vishny (1997) conditions. On the other hand, while this arbitrage is risky, a diversified portfolio across all assets would expose the trader to only the systematic risk of internet stocks. If, within a portfolio of assets, the risk of internet stocks represents purely idiosyncratic risk, then why would the capital be considered risky?

Hedge funds often face convex payout schemes. From the hedge fund's point of view, the positive skewness of internet stock returns is a negative characteristic to have in one's portfolio. The positive skewness is transparent from Table 4 which implies an annualized volatility of $117 \%$ for internet-related firms. As an illustration of the distribution of returns facing hedge funds during this period, Figure 5 graphs the crosssectional distribution of the maximum return over any month (i.e., 22-day rolling period return) for internet and non-internet firms over the January 1999 to February 2000 time period. Figure 5 shows that over $90 \%$ of the internet firms had a maximum monthly return of $80 \%$ plus over this yearly period. Thus, even if investors thought internet stocks were overvalued, there was a large probability over this year that a short position would be down considerably at some point in time. Thus, short positions might produce on average excess profits but with a substantial risk of an extreme loss. These maximum returns did not all occur at the same time, so diversification would somewhat reduce the risk over any given period. However, over this same sample period, an equally-weighted portfolio of the internet stocks had a maximum monthly return of $64 \%$. Thus, even a well-diversified portfolio of short positions would be subject to the same problems.

The fact that many investors are reluctant to short stocks immediately limits the amount of shorting that can take place. However, there are a number of other reasons why shorting stocks may be difficult in practice. First, in order to short a stock, the investor must be able to borrow it. There were only a limited number of shares available for trading in internet stocks, and someone (i.e., institution or individual) would have to 
be willing to lend the shares. For whatever reason, individuals tend to lend shares less than institutions do. Since many of the investors in internet stocks were individuals (e.g., Ofek and Richardson (2001)), this reduced on the margin the supply of shares that could be shorted. Second, there is no guarantee that the short position would not get called either through the lenders demanding it back or margin calls. It is not a $100 \%$ probability

There are a number of papers that investigate empirically the difficulty in shorting and how that can affect underlying equity prices (see, for example, D'Avolio (2001), Geczy, Musto and Reed (2001), Duffie, Garleanu and Pedersen (2002), and Ofek, Richardson and Whitelaw (2002), among others). Of particular interest to this paper, Ofek and Richardson (2001) document several stylized facts for the internet sector: (i) there was substantial more shorting taking place in the internet versus non-internet sector, (ii) the float of shares in the internet versus non-internet sector was less, and (iii) given (i) and (ii), there is evidence that the short sales constraints were binding for the internet versus non-internet sector. This latter evidence comes in several forms. First, the rebate rate on shorts was significantly lower for internet versus non-internet stocks, which suggests more internet stocks are on special. Second, there are more put-call parity violations for internet stocks than non-internet stocks, which can happen only under a number of joint conditions, one of which is short sales restrictions. Third, the crosssectional correlation between the implied P/E ratios of each stock (e.g., Figure 3) and the rebate rate is significant at the $1 \%$ level and economically large, i.e., -0.16 , which again is consistent with a binding short sale constraint.

\section{B. Possible Explanations}

In Sections III-V, we provided evidence of anomalous behavior on the part of internet stock prices. Using the evidence cited above, we can posit one explanation for why this anomalous behavior was not drowned out by rational investors, namely short sales restrictions. Nevertheless, the question remains how did the internet bubble arise in the first place? Below, we provide three brief explanations that have been described in the current literature. 
The first explanation, and one we have pushed through in our other work, is that there is heterogeneity of beliefs amongst investors. In particular, imagine a world with "optimistic" investors (dare we say, irrational ones) and "pessimistic" (rational) investors. Without short sales constraints, rational investors would short internet stocks, with "optimistic" investors simultaneously going aggressively long in these same stocks - the outcome would be some aggregation of these beliefs in the market. However, as the pessimistic investors wish to short the stock more and more, the constraint is binding and these investors can no longer short. Their beliefs will have less of an impact on asset prices, as the market clearing price no longer reflects the optimal short position, and puts more weight on the optimistic view of payoffs. Consider the extreme case in which the pessimistic investors actually leave the market and hold no stocks. In this case, asset prices will reflect only the beliefs of the optimistic investors and therefore prices increase as a result. The pessimistic investors would like to short the stocks at these inflated prices, thus bringing them down in value, but are prevented from doing so due to the short sales restrictions. This view of the world has growing support in the finance literature and seems particularly appropriate for the internet sector (e.g., Lintner (1969), Miller (1977), Jarrow (1980), Chen, Hong and Stein (2000), Jones and Lamont (2001), Duffie, Garleanu and Pedersen (2002) and Ofek and Richardson (2001) to name just a few).

Alternatively, the behavior may not be strictly irrational since the optimism could fit the theory of rational bubbles (e.g., Blanchard and Watson (1982), Froot and Obstfeld (1991) and Sheinkman and Xiong (2001)). Rational bubbles occur when investors satisfy their first order conditions from their consumption and investment decision, yet asset prices do not reflect their fundamental values, i.e., the discounted value of expected future cash flows. This is because today's price also reflects the discounted value of the future price (possibly way in the distant future) which may not equal its fundamental value. The intuition is that, even though asset prices lie above their fundamental values, investors still value the asset highly because of the possibility of even higher prices in the future. Of course, through iteration, this implies some possibility of an infinite price in the future. This and other reasons has led many researchers to question the theoretical viability of rational bubbles (e.g., Diba and Grossman (1988), Santos and Woodford 
(1997) and Cochrane (2001)). Nevertheless, by making the bubbles somewhat less than fully rational (e.g., Brunnermeier (2001)), the high internet prices are consistent with the idea of high future internet stock prices not tied to fundamental values. Unfortunately, because this future price is by nature never observed in our sample, it is difficult to provide formal evidence.

The final explanation takes the view that, as economists and practitioners, we are looking back at this period in hindsight. While there was considerable discussion during the period about the "craziness" of internet prices, and we feel much of the evidence speaks for itself, there is no doubt that very sophisticated investors, and highly regarded managers of companies, invested considerable capital in the internet sector. These investments alone suggest that a story based on an influx of irrational, retail investors is probably too simplistic. Kaplan (2002) provides a nice analysis of this alternative view of internet valuations. In particular, Kaplan (2002) focuses on growth expectations and corresponding revisions of these expectations during the 1998-2000 period.

Any cohesive explanation of the sudden rise in internet stock prices should also be able to explain their rapid fall. For explanations that are based on the presence of some irrational investors in the market, one of two conditions must change: (i) either these individuals become rational all of a sudden, or (ii) the limits of arbitrage get removed. With respect to (i), it will be difficult to explain why a large group of investors shifted their beliefs, though some of the recent rational bubble theories show promise here. In contrast, while at first glance condition (ii) does not seem promising either (i.e., why was shorting all of a sudden possible?), we actually think this is the answer. During the early spring of 2000, i.e., just before the initial crash, an incredible amount of internet firms had their shares unlocked. ${ }^{16}$ In theory, the lockup expiration eventually adds four to five times more shares to a stock's float, but, most important, it allows a whole new, presumably more rational, group of investors sell their shares in the market. That is, it unbinds the short sale constraint in a major way. In fact, in the time period before the crash, of the $\$ 900$ billion or so market value of the entire internet sector, $\$ 250$ billion worth of shares were being unlocked. This event essentially removed the short sales 
constraint on the internet sector by allowing for $25 \%-30 \%$ of the dollar value of the sector's shares to be sold directly. Therefore, the forces of arbitrage could push prices back down to more reasonable levels as rational investor's beliefs got incorporated. A detailed analysis of this event, and the explanation, is provided in Ofek and Richardson (2001).

VII. Concluding Remarks

This paper provides an analysis of some existing as well as new evidence of the relation between market prices and fundamentals in the internet sector over the period January 1998 to February 2000. While it is difficult to disprove market rationality definitively on a broad scale, we believe there is a strong, circumstantial case. This case is predicated on several important elements:

- Unlike previous examinations of market rationality, the issue cannot be isolated to a single event. Figure 2 shows that there were times when over $20 \%$ of stock market volume was being driven by internet firms. The usual explanation that these prices were not tradable, or at least not with huge quantities, is not viable here. Furthermore, if in fact asset prices were not reflecting fundamentals at these volume levels, then it requires a considerable amount of capital for rational investors to compete.

- To the extent there are specific cases, such as the internet subsidiary, the evidence is much stronger against market rationality than previous studies of non-internet firms. Moreover, in documenting the various unrelated anomalies across firms, the common characteristic is that they are internet firms. This fact alone would need to be explained to show that all the anomalies occur "by chance".

- These specific cases, along with evidence about the level of internet stock prices and their underlying fundamentals, are broadly consistent with a world in which the relevant investors have overly optimistic (or perhaps even crazy)

\footnotetext{
${ }^{16}$ In an IPO, approximately $15-20 \%$ of the shares are issued to the public. Generally, the underwriters insist upon the shares of the remaining $80-85 \%$ shareholders to be restricted from sale for a certain period of time
} 
beliefs. That is, the direction of the irrationality generally corresponds to over-optimism.

- The other evidence in this paper, i.e., the volatility of stock prices for internet firms, is more difficult to categorize. We have provided some basic stylized facts, however, on the magnitude of this volatility in relation to bid-ask spreads, which suggest that rational explanations are difficult to come by. This evidence may simply represent the amount of noise trading taking place during this period.

In conclusion, we find both the magnitude and depth of the evidence to be so great that it is hard to explain and therefore ignore. We provided several potential explanations. To us, the most promising one is a model of heterogenous agents with varying degrees of beliefs about asset payoffs who are subject to short sales constraints (e.g., Lintner (1969)). Whether this theory explains the so-called internet bubble deserves additional research.

without their express written consent. This period of time is called the lock-up period. 


\section{References}

Ball R., and Brown, P., 1968, An empirical evaluation of accounting income numbers. Journal of Accounting Research 6, 159-178.

Barber, Brad and Terence Odean, 1999, The courage of misguided convictions: The trading behavior of individual investors, Financial Analysts Journal, November/December, 41-55.

Barber, Brad and Terence Odean, 2001, The internet and the investor, Journal of Economic Perspectives, Vol. 15, 41-542.

Barber, Brad and Terence Odean, 2002, All that glitters: The effect of attention and news on the buying behavior of individual and institutional investors, working paper, UC. Berkeley.

Barclay, Michael and Jerold Warner, 1993, Stealth trading and volatility: Which trades move prices?, Journal of Financial Economics 34, 281-305.

Barclay, Michael, Robert Litzenberger and Jerold Warner, 1990, Private information, trading volume, and stock return variances, Review of Financial Studies 3, 233253.

Beckers, Stan 1983, Variances of security price returns based on high, low, and closing prices, Journal of Business, Vol.56, 97-112.

Black, Fisher, 1986, Noise, Journal of Finance 31, 529-543.

Blanchard, Olivier and Mark Watson, 1982, Bubbles, rational expectations and financial markets in Paul Wachtel, ed., Crises in the Economic and Financial Structure, Lexington, MA: Lexington Books.

Bosch, J.-C and M.. Hirschey, 1989, The valuation effects of corporate name changes, Financial Management 18, 64-73.

Brunnermeier, Marcus, Asset pricing under asymmetric information: Bubbles, crashes, technical analysis and herding, 2001, (Oxford University Press, Oxford, U.K.).

Chan, Louis, Jason Karceski and Josef Lakonsihok, 2001, The level and persistence of growth rates, NBER working paper no. 8282.

Chen, Joseph, Harrison Hong and Jeremy C. Stein, 2000, Breadth of ownership and stock returns, Harvard University.

Cochrane, John, Asset Pricing, 2001, Princeton University Press, Princeton, New Jersey.

Cooper, Michael J., Orlin Dimitrov and P. Raghavendra Rau, 2000, A rose.com by any other name, Forthcoming, Journal of Finance

Cornell, Bradford and Quao Liu, 2000, The parent company puzzle: When is the whole worth less than one of the parts, Working paper, UCLA.

D’Avolio, Gene, 2001, The market for borrowing stock, Working paper, Harvard University.

Demers, E., and Baruch Lev, 2000, A rude awakening: Internet shakeout in 2000, Working Paper, University of Rochester.

Diba, Behzad and Herschel Grossman, 1988, The theory of rational bubbles in stock prices, Economic Journal 98, 746-754.

Duffie, Darrell, Nicolae Garleanu and Lasse Pedersen, 2001, Securities lending, shorting and pricing, forthcoming Journal of Financial Economics. 
Fama, Eugene, 1970, Efficient Capital Markets: A Review of Theory and Empirical Work, Journal of Finance 25, 383-417.

Fama, Eugene F, 1998, Market efficiency, long-term returns, and behavioral finance, Journal of Financial Economics 33, 3-56.

Fama, Eugene, Fisher, Michael Jensen and Richard Roll, (1969), The Adjustment of stock prices to new information, International Economic Review 10, 1-21.

French, Kenneth R., and James M. Poterba, 1991, Were Japanese stock prices too high? Journal of Financial Economics 29, 337-363.

French, Kenneth and Richard Roll, 1986, Stock return variances: The arrival of information and the reaction of traders, Journal of Financial Economics $17,5-26$.

Froot, Kenneth and Maurice Obstfeld, 1991, Intrinsic bubbles: The case of stock prices, American Economic Review 81, 1189-1217.

Garber, Peter M., 1989, Tulipmania, Journal of Political Economy 97, 535-560.

Geczy, Christopher C., David K. Musto and Adam V. Reed, 2001, Stocks are special too: An analysis of the equity lending market, working paper, Wharton School.

Garman, M., and M. Klass, 1980, On the estimation of security price volatilities from historical data, Journal of Business 53, 67-78.

George, T.J., G. Kaul and M. Nimalendran, 1991, Estimation of the bid-ask spread and its components: A new approach, Review of Financial Studies 4, 623-656.

Glosten, L., and Larry Harris, 1988, Estimating the components of the bid-ask spread, Journal of Financial Economics 21, 123-142.

Glosten, L., and P. Milgrom, 1985, Bid, ask, and transaction prices in a specialist market with heterogeneously informed agents, Journal of Financial Economics 14, 71-100.

Hand, John R.M., 2000, The role of accounting fundamentals, web traffic, and supply and demand in the pricing of U.S internet stocks, Working paper, University of North Carolina.

Hirshleifer, D., 2001, Investor psychology and asset pricing, Journal of Finance, 56, 1533-1598.

Huang, R., and H. Stoll, 1997, The components of the bio-ask spread: A general approach, Review of Financial Studies 10, 995-1034.

Ito, Takatoshi, Richard K. Lyons and Michael T. Melvin, 1998, Is there private information in the FX market? The Tokyo experiment, Journal of Finance 3.

Jarrow, Robert, 1981, Heterogeneous expectations, restrictions on short sales, and equilibrium asset prices, Journal of Finance, Vol. 35, 1105-1113.

Jones, Charles, M., Gautam Kaul and Marc L. Lipson, 1994, Information, trading, and volatility, Journal of Financial Economics 36, 127-154.

Jones, Charles and Owen Lamont, 2001, Short sales constraints and stock returns, Working paper, University of Chicago.

Kaplan, Steven, 2002, Valuation and new economy firms, working paper, University of Chicago.

Karpoff, J.M. and G. Rankine, 1994, In search of a signaling effect: The wealth effects of corporate name changes, Journal of Banking and Finance 18, 1027-1045.

Kyle, Albert, 1985, Continuous auctions and insider trading, Econometrica 53, 1315-1335. 
Lamont, Owen and Richard Thaler, 2000, Can the market add and subtract? Mispricing in tech stock carve-outs, Working paper, University of Chicago.

Lintner, John, 1969, The aggregation of investor's diverse jugdements and preferences in purely competitive strategy markets, Journal of Financial and Quantitative Analysis 4, 347-400.

Madhavan, Ananth, Matthew Richardson and Mark Roomans, 1997, Why do security prices change? A transaction-level analysis of NYSE stocks, The Review of Financial Studies 10, 1035-1064.

Madhavan, Ananth and Seymour Smidt, 1991, A bayesian model of intraday specialist pricing, Journal of Financial Economics 30, 99-134.

Meulbroek, Lisa K., 2000, Does risk matter? Corporate insider transactions in internetbased firms, Working paper, Harvard Business School.

Miller, Edward M., 1977, Risk, uncertainty, and divergence of opinion, Journal of Finance 32, 1151-1168.

Miller, Merton H., and Modigliani Franco, 1961, Dividend, policy, growth, and the valuation of shares, Journal of Business 34, 411-433.

Mitchell, Mark, Todd Pulvino and Erik Stafford, 2001, Limited arbitrage in equity markets, Working paper, Harvard Business School.

Ofek, Eli and Matthew Richardson, 2001, DotCom Mania: The Rise and Fall of Internet Stock Prices, Working paper, New York University.

Ofek, Eli, Matthew Richardson and Robert Whitelaw, 2002, Arbitrage and short sales restrictions: Evidence from the options markets, Working paper, New York University.

Parkinson, M., 1980, The extreme value method for estimating the variance of the rate of return, Journal of Business 53, 61-65.

Santos, Manuel and Michael Woodford, 1997, Rational asset pricing models, Econometrica, 65, 19-57.

Schill, Michael J. and Chungsheng Zhou, 1999, Pricing an emerging industry: evidence from internet subsidiary carve-outs, Working paper, University of California at Riverside.

Schultz, Paul and Mir Zaman, 2000, Do the individuals closest to internet firms believe they are overhauled? Working paper, University of Notre Dame.

Schwartz, Eduardo and M. Moon, 2000, Rational pricing of internet companies, Financial Analysts Journal 56:3, 62-75.

Sheinkman, Jose and Wei Xiong, 2002, Overconfidence, short-sales constraints and bubbles, Working paper, Princeton University.

Shiller, Robert J., 1981, Do stock prices move too much to be justified by subsequent changes in dividends? A.E.R. 71, 421-436.

Shiller, Robert, 2000, Irrational exuberance, Princeton: Princeton University Press.

Shleifer, Andrei, 2000, Clarendon Lectures: Inefficient Markets, Forthcoming, Oxford University Press.

Shleifer, Andrei and Robert W. Vishny, 1997, The limits of arbitrage, Journal of Finance 52, 35-55.

Slovin, Myron B., Marie E. Sushka and Steven R. Ferraro, 1995, A comparison of the information conveyed by equity carve-outs, spin-offs, and asset sell-offs, Journal of Financial Economics 37, 189-104. 
Tezel, Ahmet and Oliver Schnusenberg, 2000, Split-Off IPOs: market returns and efficiency, Working paper, St. Joseph's University.

Vijh, Arnand M., 1999, Long-term returns from equity carve-outs, Journal of Financial Economics 51, 273-308. 


\section{Table 1A}

Internet sub-sectors and "old economy" match

A description of internet sub-industries and their mapping to non-internet industries. For each sub-industry we report the total number firms and the total number of firms with Compustat data for fiscal year 1999.

\begin{tabular}{clccl}
\hline $\begin{array}{c}\text { Industry } \\
\text { Code }\end{array}$ & Internet Industry Description & $\begin{array}{c}\text { Number of } \\
\text { firms }\end{array}$ & $\begin{array}{c}\text { Firms with } \\
\text { 12/99 data }\end{array}$ & Industry \\
\hline 1 & Internet Portal Companies & 24 & 15 & Media \\
2 & Internet Infrastructure Companies & 34 & 22 & Computer Hardware \\
3 & Internet Infrastructure Services & 74 & 47 & Computer Software \\
4 & Internet/B2B Software Companies & 54 & 28 & Information Services \\
5 & Internet Commerce Companies & 50 & 32 & Specialty Retail \\
6 & Internet Consulting/Application Services & 50 & 38 & Information Services \\
7 & Internet Financial Services Companies & 23 & 19 & Financial Services \\
8 & Multi-Sector Internet Companies & 2 & 2 & Information Services \\
9 & Internet Vertical Portal Companies & 48 & 39 & Publishing \\
10 & Internet Direct Marketing \& Advertising & 26 & 18 & Information Services \\
11 & Internet B2B Commerce Companies & 15 & 6 & Information Services \\
\hline
\end{tabular}


Table 2

Aggregate financial information and target $\mathrm{P} / \mathrm{E}$

A description of aggregate sales, market value of equity, EBITDA and earnings for internet firms with 1999 Financial data available on Compustat. Target earnings are calculated by multiplying the average Earnings/Sales ratio for all firms in the matching non-internet industry by aggregate sales for that internet sub-industry. Target $\mathrm{P} / \mathrm{E}$ is Aggregate market cap/target earnings.

\begin{tabular}{|c|c|c|c|c|c|c|c|}
\hline $\begin{array}{l}\text { Industry } \\
\text { Code }\end{array}$ & $\begin{array}{l}\text { Aggregate } \\
\text { Market cap }\end{array}$ & $\begin{array}{l}\text { Aggregate } \\
\text { sales }\end{array}$ & $\begin{array}{l}\text { Aggregate } \\
\text { EBITD } \\
\end{array}$ & $\begin{array}{l}\text { Agg.Net } \\
\text { Income }\end{array}$ & $\begin{array}{l}\text { Industry } \\
\text { margins }\end{array}$ & $\begin{array}{l}\text { Target } \\
\text { earnings }\end{array}$ & $\begin{array}{l}\text { Target } \\
P / E\end{array}$ \\
\hline All & 942,967 & 27,429 & $(5,750)$ & $(9,888)$ & 0.0568 & 1,557 & 605 \\
\hline 1 & 284,565 & 6,090 & 404 & $(1,181)$ & 0.0452 & 275 & 1035 \\
\hline 2 & 100,910 & 2,172 & 23 & 13 & 0.0474 & 103 & 980 \\
\hline 3 & 139,442 & 3,354 & $(1,562)$ & $(2,846)$ & 0.1169 & 392 & 356 \\
\hline 4 & 95,617 & 1,219 & (328) & (457) & 0.0436 & 53 & 1800 \\
\hline 5 & 72,675 & 4,459 & $(3,037)$ & $(3,565)$ & 0.0190 & 85 & 856 \\
\hline 6 & 62,697 & 3,038 & (123) & (501) & 0.0436 & 132 & 474 \\
\hline 7 & 30,968 & 3,658 & 270 & $(57)$ & 0.0927 & 339 & 91 \\
\hline 8 & 53,620 & 192 & (126) & 394 & 0.0436 & 8 & 6400 \\
\hline 9 & 43,264 & 2,267 & $(871)$ & $(1,054)$ & 0.0558 & 127 & 342 \\
\hline 10 & 31,278 & 590 & (289) & (390) & 0.0436 & 26 & 1216 \\
\hline 11 & 27,931 & 390 & (110) & (244) & 0.0436 & 17 & 1643 \\
\hline
\end{tabular}


Table 3

Panel A

Implied excess return on capital

Implied excess return on capital $\left(\mathbf{1}+\mathbf{R}^{*}\right) /(\mathbf{1}+\mathbf{R})-\mathbf{1}$ for internet firms as of 12/1999, assuming they already have profitability of comparable established industry, (ie P/E of 605)

\begin{tabular}{rrrrrr}
\hline Years & \multicolumn{5}{c}{ Terminal P/E levels } \\
& $\mathbf{1 0}$ & $\mathbf{1 5}$ & $\mathbf{2 0}$ & $\mathbf{2 5}$ & $\mathbf{3 0}$ \\
\hline $\mathbf{1 0}$ & $50.7 \%$ & $44.7 \%$ & $40.6 \%$ & $37.5 \%$ & $35.0 \%$ \\
$\mathbf{1 5}$ & $31.5 \%$ & $28.0 \%$ & $25.5 \%$ & $23.7 \%$ & $22.2 \%$ \\
$\mathbf{2 0}$ & $22.8 \%$ & $20.3 \%$ & $18.6 \%$ & $17.3 \%$ & $16.2 \%$ \\
$\mathbf{2 5}$ & $17.8 \%$ & $15.9 \%$ & $14.6 \%$ & $13.6 \%$ & $12.8 \%$ \\
$\mathbf{3 0}$ & $14.7 \%$ & $13.1 \%$ & $12.0 \%$ & $11.2 \%$ & $10.5 \%$ \\
\hline
\end{tabular}

Panel B

Implied excess return on capital

Implied growth rates $\boldsymbol{g}$ for internet firms as of $12 / 1999$. Assuming they already have profitability of comparable established industry, (ie P/E of 605 ), and that WACC $=16 \%$ during the growth period.

\begin{tabular}{rrrrrr}
\hline Years & \multicolumn{5}{c}{ Terminal P/E levels } \\
& $\mathbf{1 0}$ & $\mathbf{1 5}$ & $\mathbf{2 0}$ & $\mathbf{2 5}$ & $\mathbf{3 0}$ \\
\hline $\mathbf{1 0}$ & $74.8 \%$ & $67.9 \%$ & $63.1 \%$ & $59.5 \%$ & $56.6 \%$ \\
$\mathbf{1 5}$ & $52.5 \%$ & $48.4 \%$ & $45.6 \%$ & $43.5 \%$ & $41.7 \%$ \\
$\mathbf{2 0}$ & $42.4 \%$ & $39.6 \%$ & $37.6 \%$ & $36.0 \%$ & $34.8 \%$ \\
$\mathbf{2 5}$ & $36.7 \%$ & $34.5 \%$ & $32.9 \%$ & $31.8 \%$ & $30.8 \%$ \\
$\mathbf{3 0}$ & $33.0 \%$ & $31.2 \%$ & $30.0 \%$ & $29.0 \%$ & $28.2 \%$ \\
\hline
\end{tabular}




\section{Table 4}

Comparison of various volatility measures between internet and non-internet firms over the period 1998-2000. The sample includes 310 internet firms and 4528 non-internet firms with price greater than $\$ 10$.

\begin{tabular}{lcccccc}
\hline & Internet & Mean & Median & STD & Low & High \\
\hline \hline Daily Standard deviation of return & No & 0.0350 & 0.0300 & 0.0203 & 0.0034 & 0.3952 \\
& Yes & 0.0742 & 0.0728 & 0.0218 & 0.0135 & 0.2078 \\
& Diff & $0.0392^{\mathrm{a}}$ & $0.0428^{\mathrm{a}}$ & & & \\
\hline Average daily (high-low)/close & No & 0.0386 & 0.0325 & 0.0229 & 0.0011 & 0.2074 \\
& Yes & 0.0954 & 0.0985 & 0.0227 & 0.0059 & 0.1404 \\
& Diff & $0.0568^{\mathrm{a}}$ & $0.0660^{\mathrm{a}}$ & & & \\
\hline Implied daily STD from High Low & No & 0.0287 & 0.0239 & 0.0175 & 0.0023 & 0.4985 \\
& Yes & 0.0671 & 0.0688 & 0.0156 & 0.0068 & 0.1019 \\
& Diff & $0.0384^{\mathrm{a}}$ & $0.0449^{\mathrm{a}}$ & & & \\
\hline Bid ask spread \$ & No & 0.610 & 0.188 & 16.250 & 0.000 & 1000 \\
& Yes & 0.348 & 0.188 & 0.411 & 0.063 & 3 \\
& Diff & -0.2613 & 0.0000 & & & \\
\hline Bid ask spread/Mid price & No & 0.013 & 0.008 & 0.031 & 0.000 & 1.645 \\
& Yes & 0.007 & 0.005 & 0.007 & 0.000 & 0.058 \\
& Diff & $-0.0055^{\mathrm{a}}$ & $-0.0023^{\mathrm{a}}$ & & & \\
\hline
\end{tabular}

a - Significant at the $1 \%$ level 
Figure 1

Cumulative returns: equaly weighted internet index, S\&P 500, NASDAQ

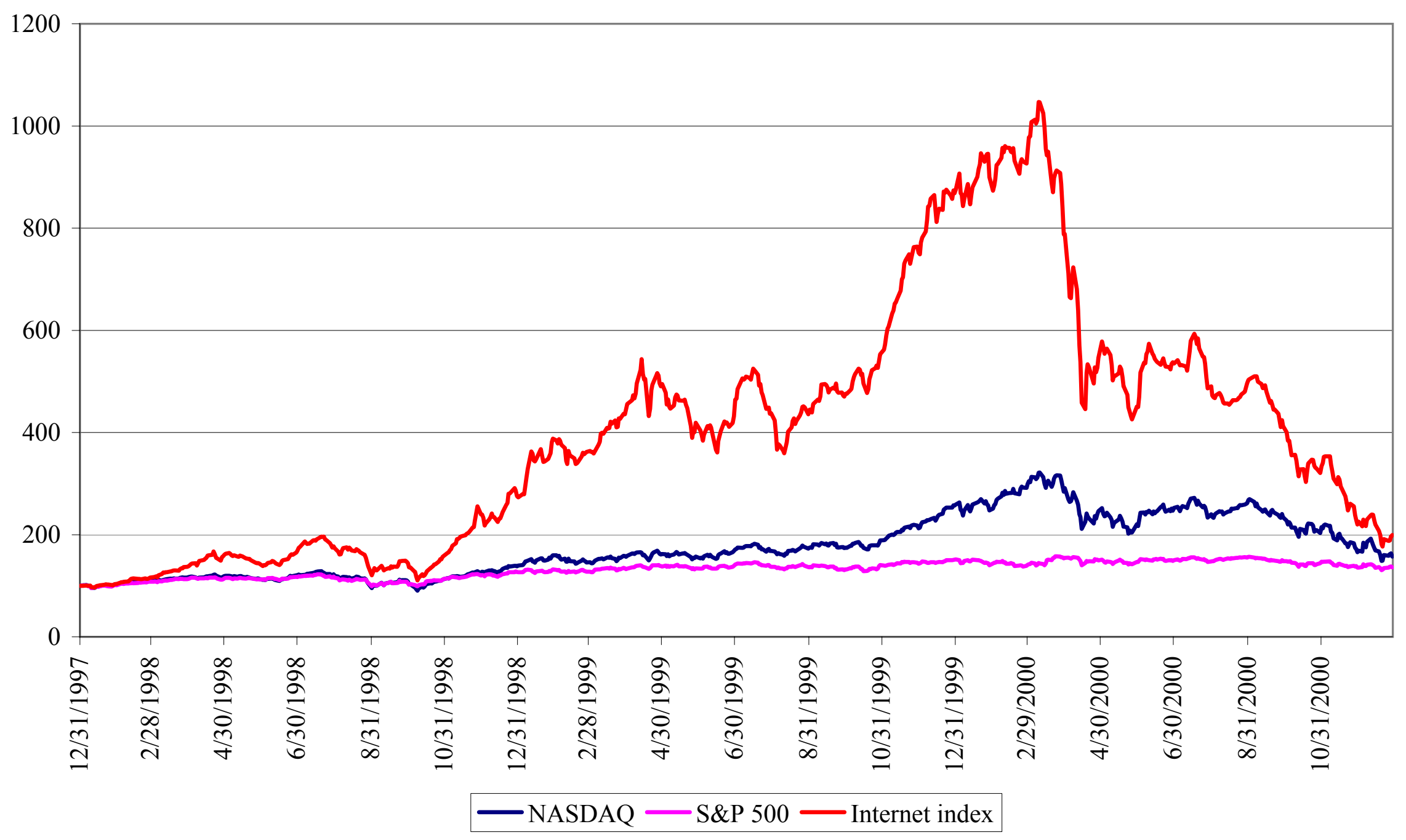


Figure 2

Fraction of internet firms in total market volume and capitalization

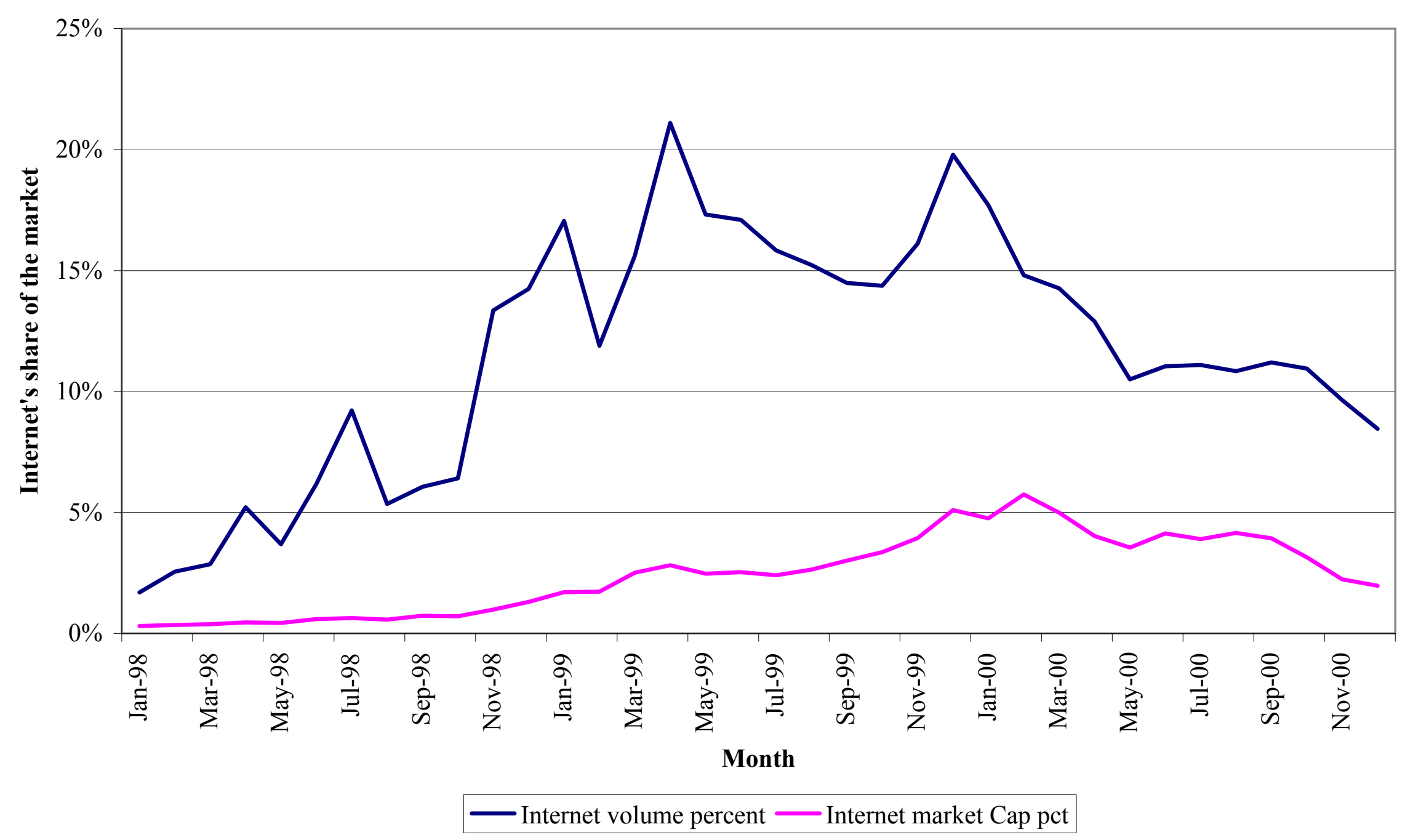


Figure 3

Histogram and cumulative frequency implied PE ratios of internet firms at the end of 1999

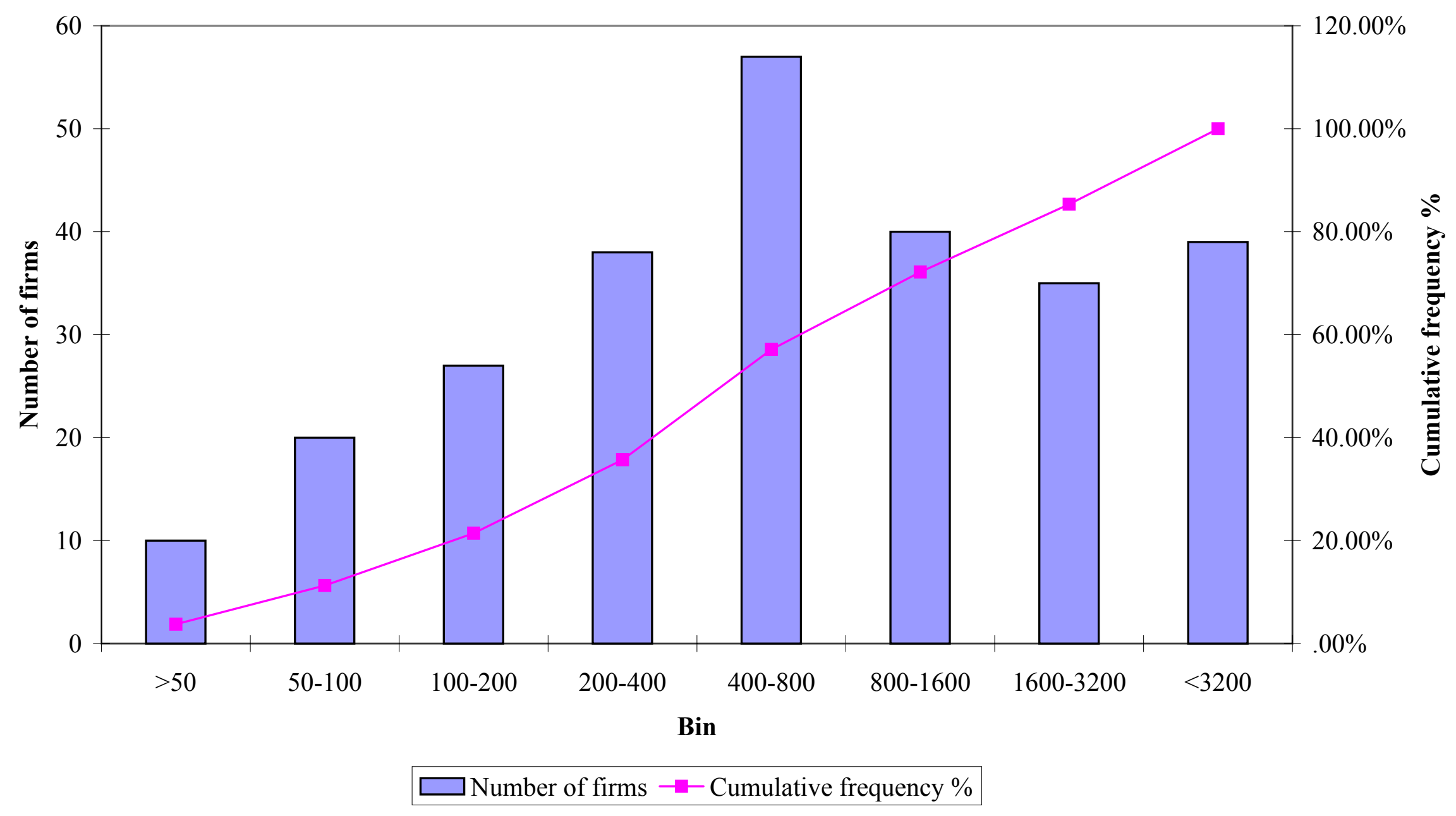




\section{Figure 4}

\section{PALM Arbitrage}

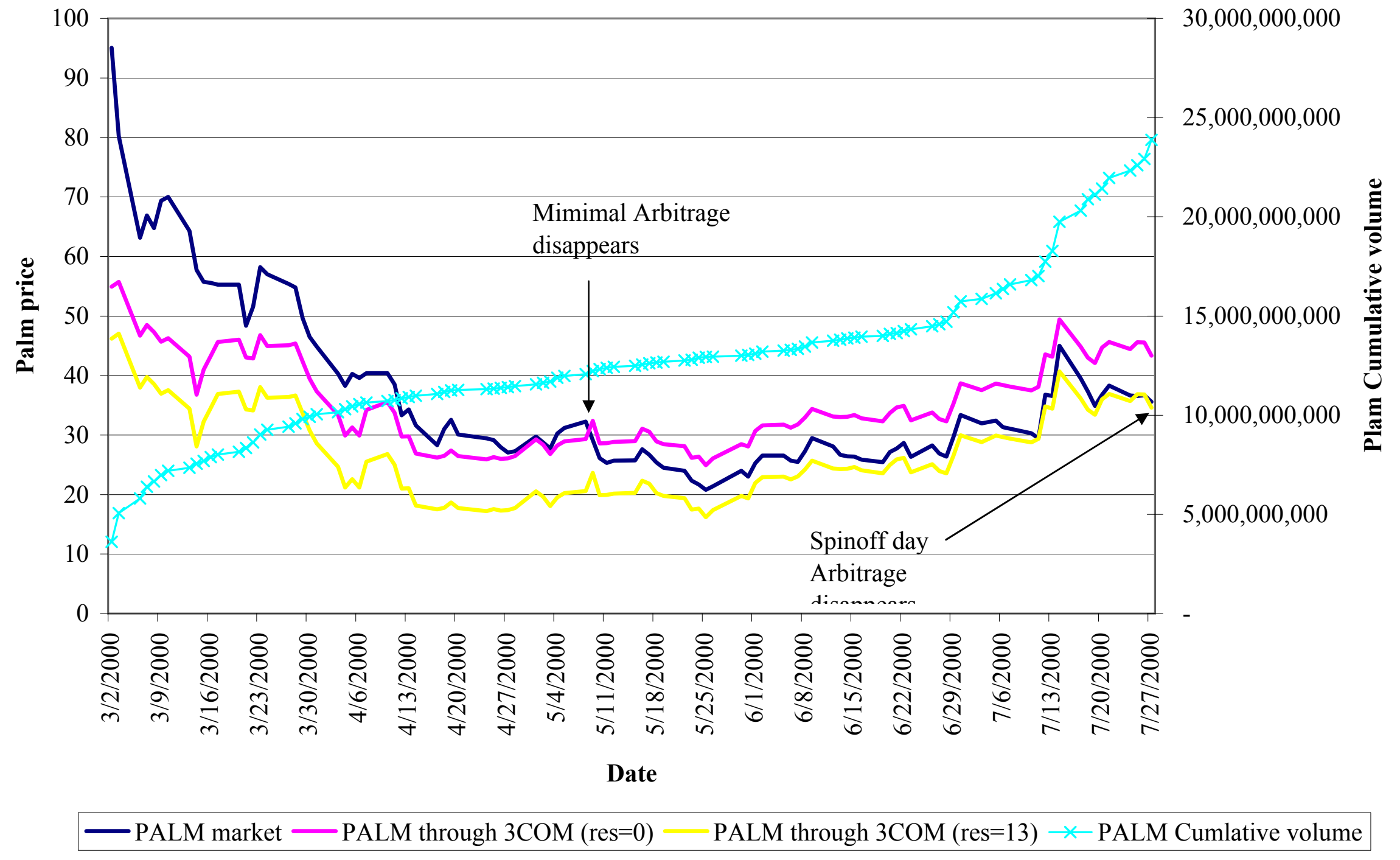




\section{Figure 5}

Frequency distribution of maximum 22 day return from 1/1/1999-2/29/2000

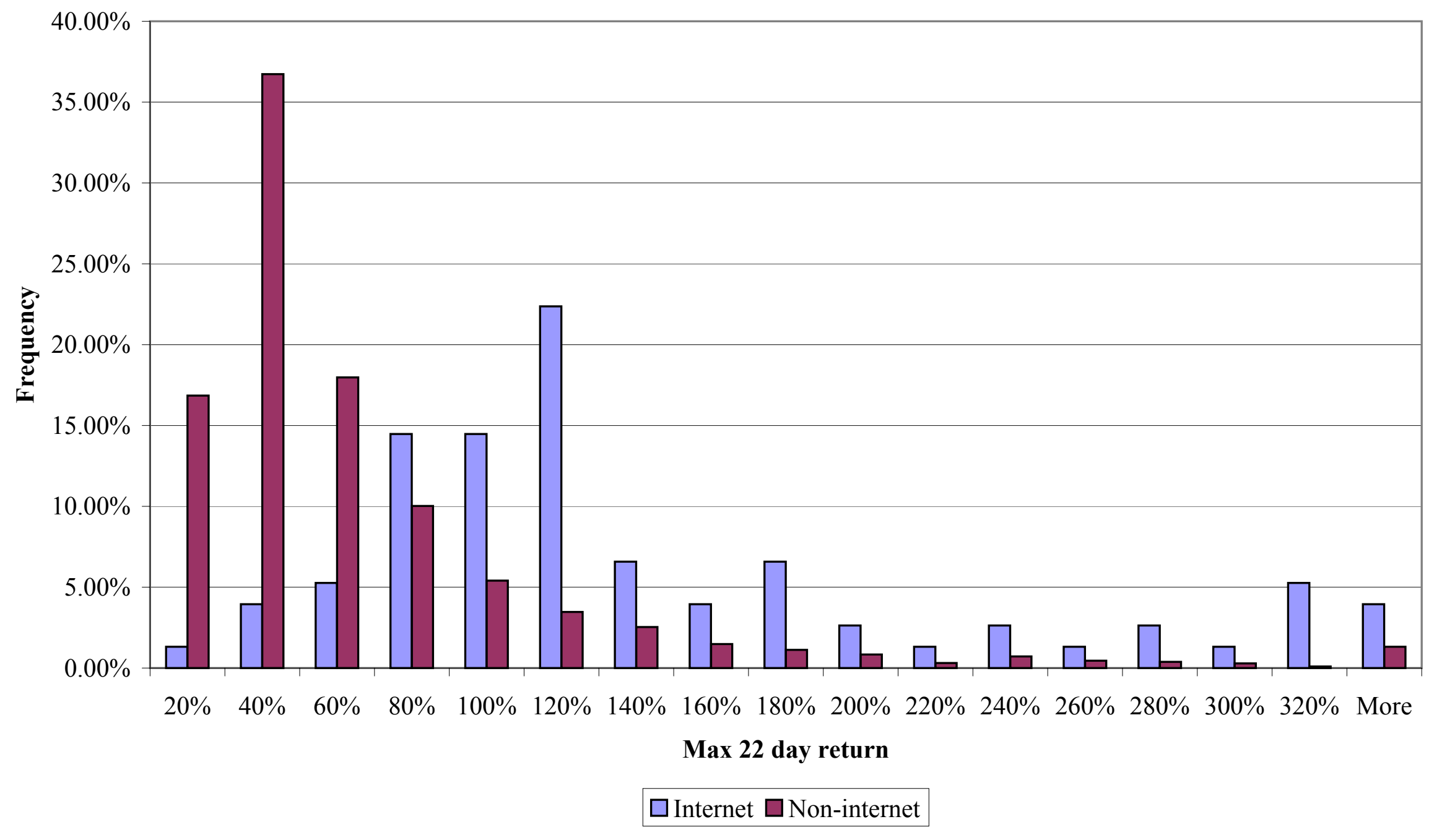

